\title{
The evaluation and determination of heavy metals pollution in edible vegetables, water and soil in the south of Tehran province by GIS
}

\author{
Hamid Shirkhanloo ${ }^{1,2 *}$, Seyed Alireza Hajiseyed Mirzahosseini ${ }^{3}$, Nasrin Shirkhanloo ${ }^{4}$, \\ Seyyed Ali Moussavi-Najarkola ${ }^{2}$ and Hadi Farahani ${ }^{1}$
}

\author{
${ }^{1}$ Research Institute of Petroleum Industry (RIPI), Iran \\ ${ }^{2}$ Iranian Petroleum Industry Health Research Institute (IPIHRI), Iran \\ Occupational and Environmental Health Research Center (OEHRC) \\ ${ }^{3}$ Islamic Azad University, Iran \\ Department of Environment and Energy, Science and Research Branch \\ ${ }^{4}$ Department of Environment, Iran
}

*Corresponding author's e-mail: hamidshirkhanloo@yahoo.ca

\begin{abstract}
Keywords: heavy metals, environmental pollution, vegetables, agricultural soil and water, Geographic Information Systems, Atomic Absorption Spectrometry.

Abstract: In this study, heavy metals pollutions in waters, soils and vegetables were investigated from farms, near oil refinery in south of Tehran city, Iran (Shahre Ray). The most important heavy metals in Iranian oil are vanadium, cobalt, nickel, arsenic and mercury ( $\mathrm{V}, \mathrm{Co}, \mathrm{Ni}, \mathrm{As}, \mathrm{Hg}$ ). In this region, the concentration of heavy metals in soils, well waters and leafy edible vegetables were evaluated in ten different points of farms. Geographic information systems (GIS) were used to estimate the levels of heavy metals concentration at unmeasured locations. After sample preparation, concentrations of heavy metals in vegetables, soils and waters were determined by atomic absorption spectrometry (AAS). Five different leafy edible vegetables from farms, i.e., Persian leek, dill, parsley, spinach and radish were sampled in spring, summer and autumn 2012. In vegetables and well water samples, the concentrations of $\mathrm{V}, \mathrm{Ni}$ and Co were above the permissible limit of heavy metals as compared to WHO guidelines and the concentrations of these metals in agricultural soils were found to be lower in accordance to soil references. The industrial waste waters had high concentration of heavy metals in this area. In consequence, the results of this study indicate that industrial waste water can cause pollution in well waters and edible vegetables. So, this region is not suitable for cultivation and growing vegetables.
\end{abstract}

\section{Introduction}

Industrial urban areas in many parts of the world have increased the presence of heavy metals into the terrestrial environment which have potential health impacts of consuming contaminated products such as vegetables (Cao et al. 2010). Perishable vegetables are often grown around urban areas, which are more prone to heavy metal contamination due to variety of urban and industrial activities. Continuous use of waste water for irrigation leads to the accumulation of heavy metals in vegetables (Amin et al. 2013). It is mentioned that plants can absorb metals from different sources such as: factories activity, fuels, agriculture activities, waste waters and environmental air pollution (Abbas et al. 2010). Leafy vegetables accumulate much higher contents of heavy metals as compared to other vegetables (Itanna 2002). Heavy metals enter waters and soils with waste waters of industrial activity and transfer to plants. Heavy metal transfer from soil to plant depends on transfer factors $(\mathrm{TF})$ and geometric mean (Ciesielczuk et al. 2014, Jonczak, et al. 2014, Uchida et al. 2007). After the entrance of heavy metals from water and soil to vegetables, these metals will enter people's diet (Zahir et al. 2009). The contributions of the vegetables to the daily intake of heavy metals from vegetables in many countries were investigated (Maleki et al. 2010). The impact of heavy metals contaminated vegetables irrigated with polluted untreated waste water from the sewage in Vinayakiya Nallah region of Jodhpur district was studied and assessed. The untreated sewage water was the main cause of soil pollution in this region that leads to the increase of toxic metal concentration in leafy vegetables grown in the fields of this area (Asdeo et al. 2011, Cheraghi et al. 2009). Edem et al. also found that leaves had highest concentrations of heavy metals such as $\mathrm{Fe}, \mathrm{Mn}, \mathrm{Cu}$ and $\mathrm{Zn}$. High concentrations of heavy metals in the leaves of the plant may affect the nutritional health of the people that consume it. Karanja et al. had studied about environmental and health 
risks associated with wastewater irrigation in partnership with farmers in Kibera and Maili Saba, Kenya (near Ngong river valley). Soil, water and crops samples from the farming and non-farming households were analyzed to elucidate sources, types and level of heavy metal pollutants in the wastewater and the pathogen loads in humans and vegetable crops. They recorded that heavy metals concentration in the stems and leaves have potential health risk, since leaves are harvested for human consumption (Edem et al. 2009, Karanja et al. 2010). In India, the Ganga River receives sizably high atmospheric inputs of heavy metals. Mid-stream water concentrations of metals showed significant correlations with their atmospheric depositions (Pandey et al. 2010). Environmental studies of Iran have shown that Isfahan has several industries located at the periphery of the city which makes the possibility of heavy metals contamination in waters and vegetables from waste water of industries. Vegetables are important part of Iranian people's diet. The daily consumption of vegetables in Iran is reported to be $278 \mathrm{~g}$ /day which is more than that of many other countries (Gharib et al. 2003). The determination of heavy metals in cultural vegetables in Shahroud city of Iran has shown that metals such as chromium $(\mathrm{Cr})$, cadmium $(\mathrm{Cd})$ and lead $(\mathrm{Pb})$ were above the standard level which was reported by Food and Agriculture Organization of the United Nations and World Health Organization (FAO/WHO). Heavy metals may be entered to agricultural waters, vegetables and foods. Finally, high concentrations of heavy metals in food chains cause a serious health risk to consumers. Acute heavy metal intoxications may damage central nervous function, the cardiovascular and gastrointestinal systems, lungs, kidneys, liver, endocrine glands, and bones. Heavy metals with adverse health effects in human metabolism present obvious concerns due to their persistence in the environment and human health consequences (Jarup et al. 2003, ATSDR 2010, NHNES 2010, ATSDR 2005). The daily dietary intake of nickel (Ni) in the United States ranges between 69-162 $\mu \mathrm{g}$ /day for humans (ATSDR 2005). The trace amounts of nickel and cobalt are indicated to be either necessary or toxic depending on their concentration range. Due to the studies on chicks and rats, nickel is apparently essential for proper liver function, or cobalt is at the core of a vitamin B12. On the other hand, some of nickel and cobalt compounds are carcinogenic (Manzoori et al. 2000, Safavi et al. 2004 and 2006, Jianget al. 2008). Arsenic is well known to be poisonous to organisms; however, the toxic effect of arsenic is highly dependent on its chemical forms in water or food. Arsenite [As (III)] is the most toxic form and is suspected to be carcinogenic. Drinking water is considered the main source of As (III) for humans (Aurilio et al. 1994, Tsuda et al. 1992). Arsenic is naturally found at low levels in air, soils, waters and organisms. However, the natural or anthropogenic sources have produced very high levels of arsenic in certain regions around the world. Foods are also considered an important part of the arsenic intake and there are only few reports of arsenic content in vegetables grown in non-polluted soils (Chakraborti et al 2002, Helgesen et al 1998, Vela et al. 2001 and 2004). Vanadium concentration less than $2 \mu \mathrm{g} \cdot \mathrm{L}^{-1}$ is essential for cell growth, but can be toxic when present at $100 \mu \mathrm{g} \cdot \mathrm{L}^{-1}$ in humans (Rehder et al. 2003, Smith et al. 1998, Tondel et al. 1999, Vinogradov et al. 1959). Mercury may enter a human body by inhalation of mercury vapor $\left(\mathrm{Hg}^{0}\right)$, drinking water $\left(\mathrm{Hg}^{2+}\right)$ and food products $\left(\mathrm{CH}_{3}-\mathrm{Hg}\right)$ in the diet. Mercury and its compounds, even at low concentration, are known to be a very dangerous neurotoxin for living organisms (Foo et al. 1998, ACGIH 2011, Jawad 2010, Sharma et al. 2009, Langmuir et al. 2004, EPA 2010, WHO 2008). Various techniques such as inductively coupled plasma mass spectrometry (Jonge et al. 2010), flame atomic absorption spectrometry (F-AAS), (Tang et al. 2012) electro-thermal atomic absorption spectrometry (ET-AAS), (Mizuguchi et al. 2011, Mohammadi et al. 2012) and cold vapor atomic absorption spectrometry (CV-AAS), (Skoog et al. 2002) are used for the determination of heavy metals in environment samples.

In this study, heavy metals such as $\mathrm{Hg}, \mathrm{As}, \mathrm{Ni}, \mathrm{Co}$ and $\mathrm{V}$ in agricultural soil, well water, waste water and vegetables grown in the vicinity of the Tehran's industrial region were determined by CV-AAS and ET-AAS. Geographic information systems (GIS) were used to estimate the metal concentration at unmeasured locations. The results of data were analyzed using statistical programmer and the correlation between soil, well water and vegetables was evaluated.

\section{Material and methods}

\section{Study area}

The study area is located in Tehran. Shahre-Ray industrial region is situated at the south of Tehran city whith an average elevation of approximately 1024 meter above mean sea level. The region covers an area of about $16\left(\mathrm{~km}^{2}\right)$ with latitude from $35^{\circ} 33.49^{\prime}$ to $35^{\circ} 32.61^{\prime} \mathrm{N}$ and longitude from $51^{\circ} 22.60^{\prime}$ to $51^{\circ} 26.01^{\prime} \mathrm{E}$. The climate of the study area is a semi-arid with average maximum temperature $17.5^{\circ} \mathrm{C}$ and the wind direction is west to east. Shahre-Ray regions generate a huge amount of pollution from industrial sectors. It is evident that an increase in contamination emission may pose substantial implications on the local agriculture, as heavy metals may enter and accumulate in agricultural products and soils (Figure 1).

\section{Sample collection}

In this study, heavy metals (As, $\mathrm{Ni}, \mathrm{Co}, \mathrm{V}$ and $\mathrm{Hg}$ ) in agricultural soils, waters and leafy edible vegetables in ten different locations in Tehran's industrial region were evaluated. For sampling, all glass tubes were washed with a $1 \mathrm{~mol} \cdot \mathrm{L}^{-1} \mathrm{HNO}_{3}$ solution for at least $24 \mathrm{~h}$ and thoroughly rinsed 8 times with ultrapure water. As determination of heavy metals concentration in leafy vegetables and soil samples are very difficult, even contamination at any stage of sampling, sample storage and handling or analysis has the potential to affect the accuracy of the results. Agricultural soil, well water and leafy edible vegetables (Persian leek, dill, parsley, spinach and radish - leaf) were sampled in the spring, summer and autumn of 2012. Each place of soil and vegetable sampling had five points included, center point and four locations in north, south, east and west 10 meters of the center (Figure 1, Table1). Samples of leafy vegetables (Persian leek, dill, parsley, spinach and radish - leaf) and agricultural soil were collected from ten places in the south of Tehran Province (Shahre-Ray). In each point five samples were collected 10 meters from the center point for soil and vegetables. Soil samples were prepared in 3 terms of harvesting by $1 \mathrm{Cm}, 10 \mathrm{Cm}$ and $20 \mathrm{Cm}$ from surface and mixed thoroughly to one sample $(10 \times 5 \times 3 \times 1)$ and samples of five leafy vegetables were similarly prepared $(10 \times 5 \times 5 \times 3)$. The well water and waste water samples collected near 
industrial region based on standard method were prepared in 3 terms of harvesting $(20 \times 3)$. The sample collection included 750 leafy edible vegetable, 150 agricultural soil and 60 water samples (summarize 960 samples).

\section{Apparatus and Materials}

Determination of heavy metals ( $\mathrm{Hg}, \mathrm{As}, \mathrm{Ni}, \mathrm{Co}, \mathrm{V})$ was performed with a spectra GBC electro-thermal atomic absorption spectrometer (Plus 932, Australia) using a graphite furnace and cold vapor module (GF3000, HG3000, GBC). The operating parameters for the metal of interest were set as recommended by the manufacturer. All samples in ET-AAS were performed using $20 \mu \mathrm{L}$ of samples. Microwave digestions were carried out with a Multi-Wave 3000 (sample volume; $100 \mathrm{~mL}$, perasure; 20 bar, Anton Paar, Austria). The instrumental and temperature programming for the graphite atomizer are listed in Table 2. All reagents were of ultra-trace analytical grade from Merck (Germany) and Aldrich (Germany). The standard solutions ( $\mathrm{Hg}, \mathrm{As}, \mathrm{Ni}, \mathrm{Co}$ and $\mathrm{V}$ ) as a stock solution was prepared from an appropriate amount of nitrate salts of these analytes as $1000 \mathrm{mg} \cdot \mathrm{L}^{-1}$ solution in $0.01 \mathrm{~mol} \cdot \mathrm{L}^{-1} \mathrm{HNO}_{3}$ (Merck). All of standard solutions were prepared daily by dilution of the stock solution. Ultrapure water $(18 \mathrm{M} \Omega \cdot \mathrm{cm})$ was obtained from Millipore Continental Water System (Bedford, USA).

\section{Sample preparation and treatment}

Water, soil and vegetable samples were placed in polyethylene bags and analyzed by laboratory of IPIOEHRC. The vegetable samples were washed with tap water followed with double de-ionized distil water (DDW). Leafy vegetable samples were cut into small pieces and dried at $105^{\circ} \mathrm{C}$ for 18 hours. After

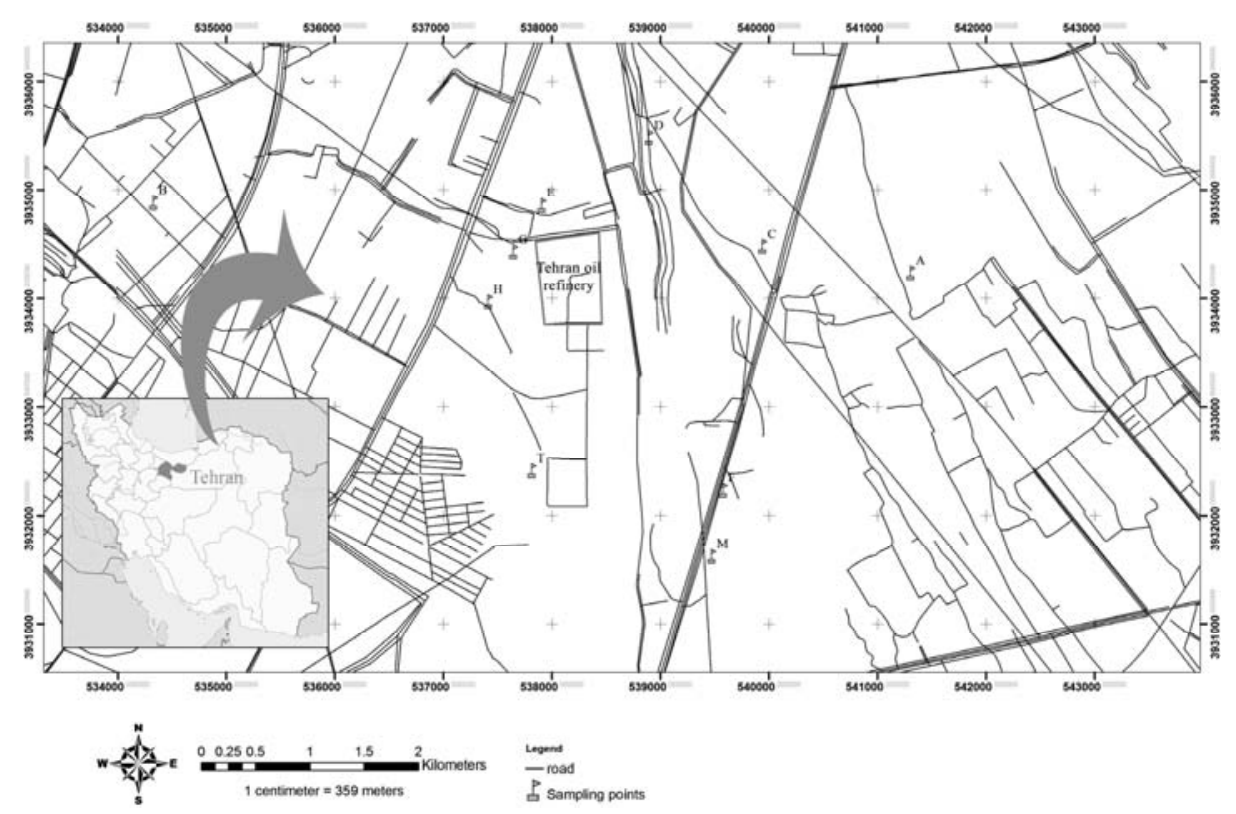

Fig. 1. The location and geology map of study area with surface water, soil and leafy edible vegetable sampling points

Table 1. Geographical sampling in ten point located of Tehran's industrial region (5 samples) include center point and north, south, east and west point 10 meters distance from center)

\begin{tabular}{|c|c|c|}
\hline Sampling sites & Geographi & ates center \\
\hline$A$ & N 35³3'3.40" & E $51^{\circ} 27^{\prime} 20.68^{\prime \prime}$ \\
\hline B & 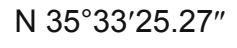 & E $51^{\circ} 22^{\prime} 43.87^{\prime \prime}$ \\
\hline $\mathrm{C}$ & N 353' $11.44^{\prime \prime}$ & E $51^{\circ} 26^{\prime} 26.65^{\prime \prime}$ \\
\hline $\mathrm{D}$ & 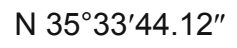 & E $51^{\circ} 25^{\prime} 45.25^{\prime \prime}$ \\
\hline$E$ & 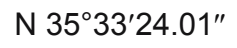 & E $51^{\circ} 25^{\prime} .96^{\prime \prime}$ \\
\hline$F$ & N 35³1'58.60" & 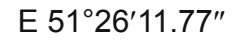 \\
\hline $\mathrm{H}$ & N 353'ㄷ․ $55.10^{\prime \prime}$ & E $51^{\circ} 24^{\prime} 46.18^{\prime \prime}$ \\
\hline G & N $35^{\circ} 33^{\prime} 10.18^{\prime \prime}$ & E $51^{\circ} 24^{\prime} 55.45^{\prime \prime}$ \\
\hline$M$ & N 3531'38.91" & E $51^{\circ} 26^{\prime} 7.45^{\prime \prime}$ \\
\hline $\mathrm{T}$ & 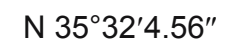 & E $51^{\circ} 25^{\prime} 1.94^{\prime \prime}$ \\
\hline
\end{tabular}


Table 2. Instrumental parameters and temperature program for the graphite atomizer

\begin{tabular}{llllll}
\hline Parameter & $\mathrm{Ni}$ & $\mathrm{Co}$ & $\mathrm{Hg}$ & $\mathrm{As}$ & $\mathrm{V}$ \\
\hline Wavelength $(\mathrm{nm})$ & 232.0 & 240.7 & 253.7 & 197.2 & 318.5 \\
Lamp current $(\mathrm{mA})$ & 4 & 6 & 3 & 8 & 18 \\
Spectral bandwidth $(\mathrm{nm})$ & 0.2 & 0.2 & 0.5 & 1 & 0.2 \\
LOD $\left(\mu \mathrm{g} \cdot \mathrm{L}^{-1}\right)$ & 2 & 1 & 0.2 & 0.5 & 5 \\
Working range $\left(\mu \mathrm{g} \cdot \mathrm{L}^{-1}\right)$ & $5-65$ & $3-45$ & $1-55$ & $1-10$ & $20-240$ \\
Method & ET-AAS & ET-AAS & CV-AAS & HG-AAS & ET-AAS \\
\hline Temperature Program & & & & & \\
\hline & $\mathrm{Ni}$ & Co & $\mathrm{V}$ & Ramp(s) & Hold(s) \\
Drying & 120 & 120 & 120 & 10 & 10 \\
Ashing & 900 & 800 & 1200 & 40 & 5 \\
Atomization & 2400 & 2300 & 2700 & 1 & 3 \\
\hline
\end{tabular}

drying the samples were ground into powder form. Briefly, $5 \mathrm{~g}$ of the dry leafy vegetables and soil sample was placed in a $100 \mathrm{~mL}$ decomposition polyethylene tube to which were added $2 \mathrm{~mL}$ of $10 \%(\mathrm{w} / \mathrm{v}) \mathrm{H}_{2} \mathrm{O}_{2}$ and $10 \mathrm{~mL} \mathrm{HNO}_{3}$ concentrate. The mixture was digested by heating and irradiating for $60 \mathrm{~min}$ by microwave. After heating the sample at $120^{\circ} \mathrm{C}$ the sample volume was set up to $10 \mathrm{~mL}$ and metal concentration was achieved based on metal mass $(\mu \mathrm{g})$ in $5 \mathrm{~g}$ of sample $(\mu \mathrm{g} / \mathrm{g})$. The water samples $(5 \mathrm{~mL})$ were digested by $1 \mathrm{~mL}$ of $10 \%(\mathrm{w} / \mathrm{v})$ $\mathrm{H}_{2} \mathrm{O}_{2}$ and $5 \mathrm{~mL}$ of concentrate $\mathrm{HNO}_{3}$ and after heating set up to $2 \mathrm{~mL}$, the concentration factor $(\mathrm{CF})$ of 2.5 was achieved $(\mu \mathrm{g} / \mathrm{L})$. All samples of well waters, soils and vegetables were analyzed by AAS, after pre-concentration and dilution.

Following the instruction of instrument operational manual provided by the manufacturer, the analysis of $\mathrm{Ni}$, $\mathrm{Co}, \mathrm{V}$, As and $\mathrm{Hg}$ was carried out using atomic absorption spectrophotometer coupled with graphite furnace, cold vapor and hydride generation assembly. Ni, Co and $\mathrm{V}$ were analyzed on electro thermal atomic absorption spectrophotometer (ET-AAS) and $\mathrm{Hg}$ and As determined by using cold vapor or hydride generation Assembly (CV-AAS, HG-AAS) respectively. The blank solutions proceeded the same way and were used for the preparation of the calibration solutions and for measurement of the blanks. In the present study, the heavy metal concentrations are used to prepare a sampling inventory, which will be computed and stored in databases of geographic information systems (GIS). Tools like GIS have helped to make use of the sampling data to estimate the levels of heavy metal concentration at unmeasured locations (Wilhelm et al. 2003).

The data were spline interpolated using the interpolation technique at a $3 \mathrm{Km}$ resolution, and finally imported into ArcGIS 9.2 where cell values express the heavy metals concentration in sampling point. The spline method is an interpolation method that estimates values using a mathematical function that minimizes overall surface curvature, resulting in a smooth surface that passes exactly through the input points.

\section{Results and discussion}

Heavy metals are of great significance in eco-chemistry and eco-toxicology because of their toxicity at low levels and tendency to accumulate in human organs. The dietary limit of metals in food, vegetable and soil is very important and permissible limits of the metals in agricultural soils, waters and vegetables have been reported by FAO/WHO (Table 3). Mean concentrations of $\mathrm{Ni}, \mathrm{Co}, \mathrm{V}$, As and $\mathrm{Hg}$ in agricultural soil, well water and vegetables were obtained in spring, summer and autumn season (Table 4). In waste water, the mean concentrations of $\mathrm{V}, \mathrm{Ni}, \mathrm{Co}$, As and $\mathrm{Hg}$ were $411.63 \pm 21.88 \mu \mathrm{g} \cdot \mathrm{L}^{-1}, 388.28 \pm 19.09 \mu \mathrm{g} \cdot \mathrm{L}^{-1}$, $216.73 \pm 10.12 \mu \mathrm{g} \cdot \mathrm{L}^{-1}, 8.33 \pm 0.37 \mu \mathrm{g} \cdot \mathrm{L}^{-1}$ and $7.89 \pm 0.42 \mu \mathrm{g} \cdot \mathrm{L}^{-1}$ respectively. Heavy metals contaminated vegetables which were irrigated with polluted well water from the sewage and waste water in industrial area of Shahre-Ray were studied. Accumulation of toxic heavy metals in vegetables irrigated with polluted well water was investigated and measured. The agricultural well waters and industrial waste water have high concentration of $\mathrm{V}, \mathrm{Ni}$ and $\mathrm{Co}$ in all of samples. According to Figures 2 and 3, six points ( $g, f, h, m, t$ and e) near Shahre-Ray industrial region have higher concentration of heavy metals in leafy vegetables than those in other points. The agricultural soil samples had low concentration of heavy metals in all sampling points as compared to soil references. All results of this study were reported after three determinations and repeatability $(\mathrm{RSD}<5 \%)$. The correlations of the results showed that the relationship between the concentration of metals in soils and vegetables was significant statistically $(\mathrm{r}=0.581$ and $P<0.017$ ) and the relationship of $\mathrm{V}, \mathrm{Ni}$ and Co between well waters and vegetables was significant statistically $(\mathrm{r}=0.691$ and $P<0.013$ ). Also, the correlation test showed significant relations of waste water with soil, well water and vegetables in the samples (Table 5).

\section{Vanadium}

The results of this study showed that among the five groups of vegetables, the maximum concentration of vanadium was found in spinach $\left(0.121 \pm 0.006 \mu \mathrm{g} \cdot \mathrm{g}^{-1}\right)$ whereas the minimum concentration was in radish $\left(0.068 \pm 0.005 \mu \mathrm{g} \cdot \mathrm{g}^{-1}\right)$. The mean concentration of vanadium in edible vegetables, agricultural well waters and soils were $0.093 \pm 0.005 \mu \mathrm{g} \cdot \mathrm{g}^{-1}, 182.23 \pm$ $7.45 \mu \mathrm{g} \cdot \mathrm{L}^{-1}$ and $0.457 \pm 0.027 \mu \mathrm{g} \cdot \mathrm{g}^{-1}$ respectively (Tables 4 and 6). So, agricultural well waters can cause vanadium pollution in edible vegetables and soil. Maximum concentrations of vanadium were observed in $\mathrm{G}$ and $\mathrm{H}$ points. Figure 4 indicates that the highest vanadium level occurs in the vicinity of the 
Table 3. Permissible limits of the metals in soil, water and vegetables (FAO/WHO)

\begin{tabular}{llllll}
\hline WHO & $\mathrm{Ni}$ & $\mathrm{Co}$ & $\mathrm{V}$ & $\mathrm{Hg}$ & As \\
\hline Soila $^{\mathrm{a}}$ & $2-40$ & $0.1-50$ & 0.5 & $0-0.3$ & $1-30$ \\
Vegetables $^{\mathrm{a}}$ & 0.10 & 0.01 & 0.03 & 0.03 & 0.50 \\
Water $^{\mathrm{b}}$ & 0.07 & 0.08 & 0.10 & 0.006 & 0.01 \\
\hline
\end{tabular}

${ }^{\mathrm{a}} \mu \mathrm{g} \mathrm{g} \mathrm{g}^{-1}$

${ }^{\mathrm{b}} \mathrm{mg} \mathrm{L}^{-1}$

Table 4. Mean concentration of metals in vegetables, soil and water samples in spring, summer and autumn 2012 (The concentrations of metals justified with dilution of samples by $\mathrm{DW}, \mathrm{N}=10$ )

\begin{tabular}{llllll}
\hline Sample & & & Metal Concentration $^{\mathrm{a}}$ & \\
\hline Vegetables $^{\mathrm{b}}$ & $\mathrm{V}$ & $\mathrm{Ni}$ & $\mathrm{Co}$ & $\mathrm{Hg}$ & $\mathrm{As}$ \\
Spring & $0.064 \pm 0.006$ & $0.521 \pm 0.022$ & $0.068 \pm 0.003$ & $\mathrm{ND}$ & $0.413 \pm 0.031$ \\
Summer & $0.114 \pm 0.005$ & $0.932 \pm 0.061$ & $0.079 \pm 0.007$ & $0.034 \pm .003$ & $0.732 \pm 0.033$ \\
Autumn & $0.101 \pm 0.004$ & $0.872 \pm 0.046$ & $0.072 \pm 0.002$ & $0.020 \pm 0.002$ & $0.379 \pm 0.020$ \\
Mean & $0.093 \pm 0.005$ & $0.775 \pm 0.043$ & $0.073 \pm 0.004$ & $0.027 \pm 0.002$ & $0.508 \pm 0.028$ \\
\hline Well Water ${ }^{c}$ & $\mathrm{~V}$ & $\mathrm{Ni}$ & $\mathrm{Co}$ & $\mathrm{Hg}$ & $\mathrm{As}$ \\
Spring & $115.57 \pm 5.23$ & $77.08 \pm 2.56$ & $83.02 \pm 4.23$ & $\mathrm{ND}$ & $0.49 \pm 0.01$ \\
Summer & $243.13 \pm 9.17$ & $237.68 \pm 5.25$ & $191.57 \pm 6.88$ & $0.22 \pm 0.02$ & $1.12 \pm 0.04$ \\
Autumn & $187.99 \pm 7.95$ & $202.53 \pm 4.58$ & $104.82 \pm 4.46$ & $0.08 \pm 0.01$ & $0.67 \pm 0.01$ \\
Mean & $182.23 \pm 7.45$ & $172.43 \pm 4.13$ & $126.47 \pm 5.19$ & $0.15 \pm 0.01$ & $0.76 \pm 0.02$ \\
\hline Soil ${ }^{b}$ & $\mathrm{~V}$ & $\mathrm{Ni}$ & $\mathrm{Co}$ & $\mathrm{Hg}$ & $\mathrm{As}$ \\
Spring & $0.215 \pm 0.016$ & $1.152 \pm 0.029$ & $0.453 \pm 0.028$ & $\mathrm{ND}$ & $0.72 \pm 0.062$ \\
Summer & $0.634 \pm 0.042$ & $3.974 \pm 0.045$ & $0.712 \pm 0.037$ & $0.085 \pm 0.006$ & $1.38 \pm 0.062$ \\
Autumn & $0.522 \pm 0.023$ & $2.230 \pm 0.022$ & $0.536 \pm 0.031$ & $\mathrm{ND}$ & $1.14 \pm 0.062$ \\
Mean & $0.457 \pm 0.027$ & $2.452 \pm 0.032$ & $0.567 \pm 0.032$ & $0.085 \pm 0.006$ & $1.08 \pm 0.062$ \\
\hline
\end{tabular}

${ }^{a}$ Mean of three determinations \pm confidence interval $(P=0.95, n=5)$

${ }^{\mathrm{b}} \mu \mathrm{g} \mathrm{g}^{-1}$

${ }^{\mathrm{c}} \mu \mathrm{g} \mathrm{L} \mathrm{L}^{-1}$

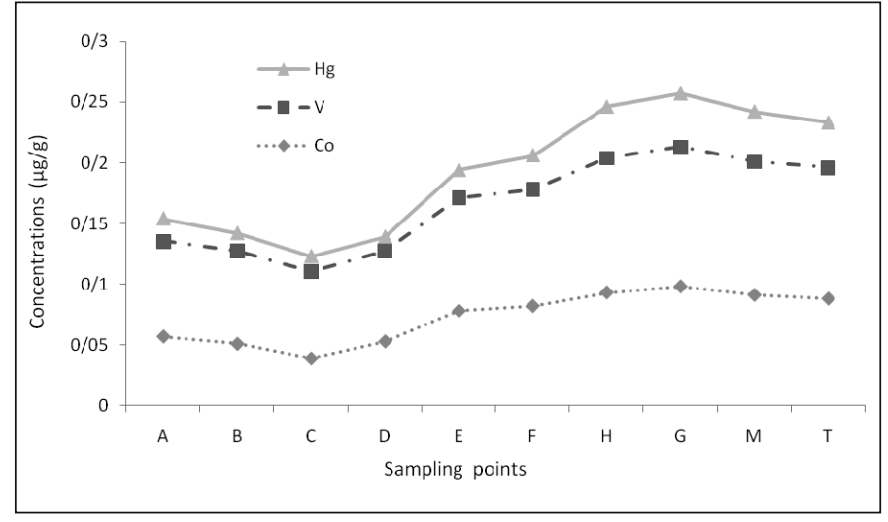

Fig. 2. Concentration of $\mathrm{Co}, \mathrm{V}$ and $\mathrm{Hg}$ in ten point sampling of leafy vegetables

industrial area and the concentration levels for the stations of $\mathrm{G}, \mathrm{H}$ and $\mathrm{M}$ are in the range of $0.114-0.102 \mu \mathrm{g} \cdot \mathrm{g}^{-1}$. The concentration or vanadium in industrial waste water was $312.23 \pm 9.86 \mu \mathrm{g} \cdot \mathrm{L}^{-1}$.

\section{Nickel}

Based on the obtained results, the maximum and minimum concentrations of nickel were found in radish

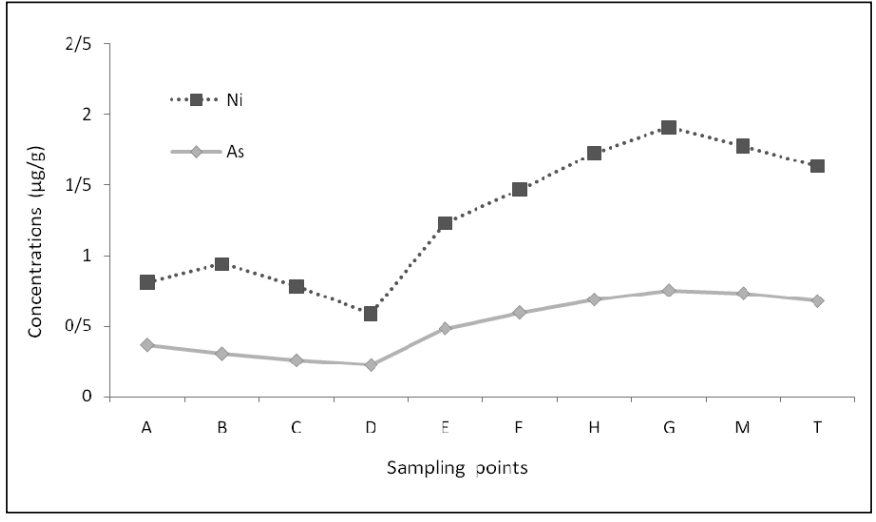

Fig. 3. Concentration of $\mathrm{As}$ and $\mathrm{Ni}$ in ten point sampling of leafy vegetables

$\left(1.003 \pm 0.045 \mu \mathrm{g} \cdot \mathrm{g}^{-1}\right)$ and parsley $\left(0.498 \pm 0.035 \mu \mathrm{g} \cdot \mathrm{g}^{-1}\right)$ respectively. The mean concentrations of nickel in leafy vegetables, agricultural soil and well water were $0.775 \pm$ $0.043 \mu \mathrm{g} \cdot \mathrm{g}^{-1}, 2.452 \pm 0.032 \mu \mathrm{g} \cdot \mathrm{g}^{-1}$ and $172.43 \pm 4.13 \mu \mathrm{g} \cdot \mathrm{L}^{-1}$ respectively (Tables 4 and 6). Nickel has a high concentration in edible vegetables and well waters as compared with WHO references. Highest concentrations of nickel were observed in $\mathrm{G}$ and $\mathrm{H}$ points. The maximum vanadium level occurred in the 
Table 5. Correlation of heavy metals in well water with soil and vegetables and soil with vegetables $(n=960)$

\begin{tabular}{lccccccc}
\hline Metals & $\mathrm{R}^{2}$ & \multicolumn{2}{c}{ Water-Soil } & \multicolumn{2}{c}{ Water-Vegetables } & \multicolumn{2}{c}{ Soil-Vegetables } \\
\hline & & $r$ & P value & $r$ & P value & $r$ & $P$ value \\
\hline $\mathrm{V}$ & 0.9965 & 0.354 & 0.023 & 0.684 & 0.012 & 0.532 & 0.011 \\
$\mathrm{Ni}$ & 0.9957 & 0.426 & 0.032 & 0.722 & 0.009 & 0.525 & 0.019 \\
$\mathrm{Co}$ & 0.9973 & 0.313 & 0.038 & 0.667 & 0.017 & 0.589 & 0.026 \\
$\mathrm{Hg}$ & 0.9997 & 0.362 & 0.037 & 0.321 & 0.031 & 0.675 \\
$\mathrm{As}$ & 0.9978 & 0.389 & 0.041 & 0.412 & 0.024 & 0.013 \\
Mean & 0.9974 & 0.369 & 0.034 & 0.561 & 0.019 & 0.017 \\
\hline
\end{tabular}

${ }^{*}$ Correlations ( $r$ ), Statistical significance will be observed if $P<0.05$.

Table 6. Metal concentration in edible vegetables in Tehran industrial zone

\begin{tabular}{llcccc}
\hline Metal & Persian leek & Dill & Parsley & Spinach & Radish-leaf \\
\hline $\mathrm{V}$ & $0.102 \pm 0.004$ & $0.075 \pm 0.003$ & $0.099 \pm 0.005$ & $0.121 \pm 0.006$ & $0.068 \pm 0.005$ \\
\hline $\mathrm{Ni}^{\mathrm{a}}$ & $0.611 \pm 0.042$ & $0.842 \pm 0.038$ & $0.498 \pm 0.035$ & $0.921 \pm 0.056$ & $1.003 \pm 0.045$ \\
\hline $\mathrm{Co}^{\mathrm{a}}$ & $0.091 \pm 0.005$ & $0.048 \pm 0.003$ & $0.037 \pm 0.003$ & $0.107 \pm 0.004$ & $0.082 \pm 0.005$ \\
\hline $\mathrm{Hg}^{\mathrm{a}}$ & $0.024 \pm 0.001$ & $\mathrm{ND}^{\mathrm{b}}$ & $\mathrm{ND}^{\mathrm{b}}$ & $0.038 \pm 0.003$ & $0.018 \pm 0.001$ \\
\hline $\mathrm{As}^{\mathrm{a}}$ & $0.203 \pm 0.028$ & $0.543 \pm 0.028$ & $0.632 \pm 0.028$ & $0.811 \pm 0.028$ & $0.351 \pm 0.028$ \\
\hline
\end{tabular}

${ }^{\mathrm{a}} \mu \mathrm{g} \mathrm{g} \mathrm{g}^{-1}$

${ }^{\mathrm{b}}$ Not Detection

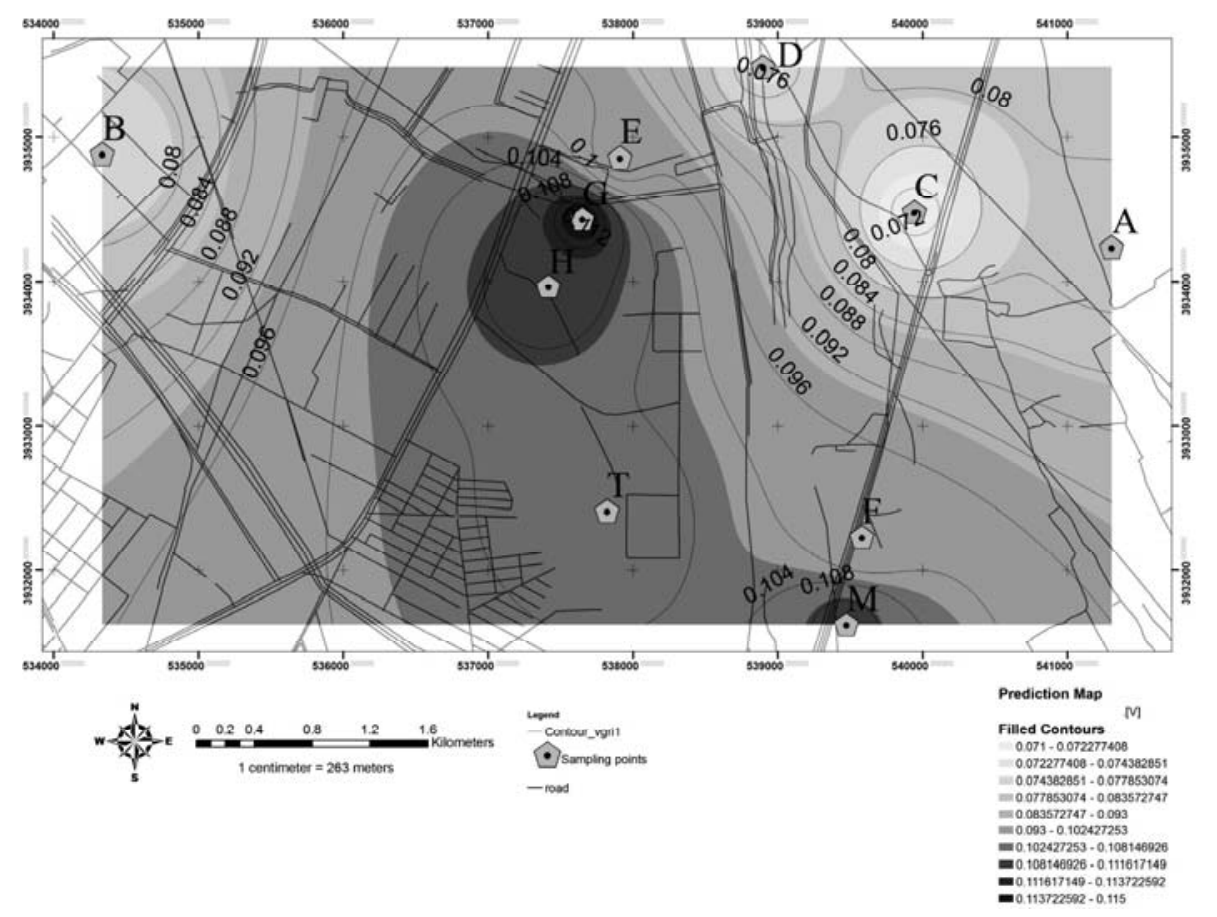

Fig. 4. Spatial distribution of $V$ as calculated by interpolation method for leafy vegetables using information system

vicinity of the industrial region and the concentration levels for the stations of $\mathrm{G}, \mathrm{H}$ and $\mathrm{M}$ were in the range of $1.12-0.88 \mu \mathrm{g} \cdot \mathrm{g}^{-1}$ (Figure 5). The concentration or nickel in waste water was $242.28 \pm 8.94 \mu \mathrm{g} \cdot \mathrm{L}^{-1}$.

\section{Cobalt}

The results of our study showed that the maximum and minimum concentrations of cobalt were found in spinach $\left(0.107 \pm 0.004 \mu \mathrm{g} \cdot \mathrm{g}^{-1}\right)$ and parsley $\left(0.037 \pm 0.003 \mu \mathrm{g} \cdot \mathrm{g}^{-1}\right)$ respectively. The mean concentrations of cobalt in five leafy vegetables, agricultural soil and well water were $0.073 \pm$ $0.004 \mu \mathrm{g} \cdot \mathrm{g}^{-1}, 0.567 \pm 0.032 \mu \mathrm{g} \cdot \mathrm{g}^{-1}$ and $126.47 \pm 5.19 \mu \mathrm{g} \cdot \mathrm{L}^{-1}$ respectively (Tables 4 and 6 ). Cobalt has a high concentration in edible vegetables and well water as compared with WHO references. The maximum of cobalt level was obtained at the center of the studied area and the concentration levels 


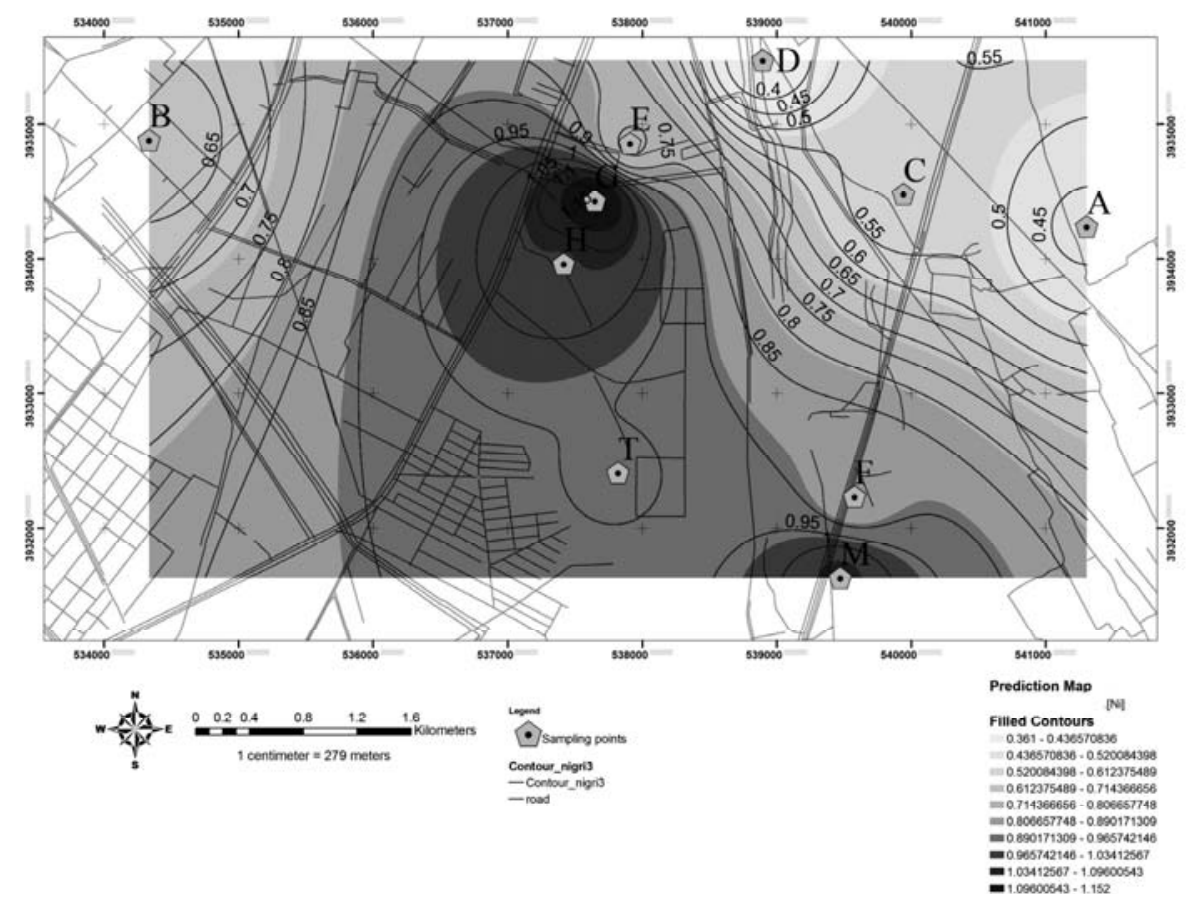

Fig. 5. Spatial distribution of $\mathrm{Ni}$ as calculated by interpolation method for leafy vegetables using information system

for $\mathrm{G}$ and $\mathrm{H}$ points were in the range of $0.097-0.081 \mu \mathrm{g} \cdot \mathrm{g}^{-1}$ (Figure 6). The mean concentrations of cobalt in waste water samples were achieved as $214.32 \pm 7.05 \mu \mathrm{g} \cdot \mathrm{L}^{-1}$.

\section{Mercury}

This study showed that the maximum concentration of mercury was found in spinach $\left(0.038 \pm 0.003 \mu \mathrm{g} \cdot \mathrm{g}^{-1}\right)$ and the lower concentration was obtained in dill and parsley. The mean concentrations of mercury in five leafy vegetables, agricultural soil and well water were $0.027 \pm 0.002 \mu \mathrm{g} \cdot \mathrm{g}^{-1}$, $0.085 \pm 0.006 \mu \mathrm{g} \cdot \mathrm{g}^{-1}$ and $0.15 \pm 0.01 \mu \mathrm{g} \cdot \mathrm{L}^{-1}$ respectively (Tables 4 and 6). The maximum mercury levels occurred in $\mathrm{G}$ and $\mathrm{H}$ points with the concentration levels between 0.042-0.032 $\mu \mathrm{g} \cdot \mathrm{g}^{-1}$. According to experimental results, mercury had a low concentration in edible vegetables, agricultural soil and water as compared with WHO/FDA references, (Figure 7). The concentration of mercury in waste water samples was achieved as $3.12 \pm 0.08 \mu \mathrm{g} \cdot \mathrm{L}^{-1}$.

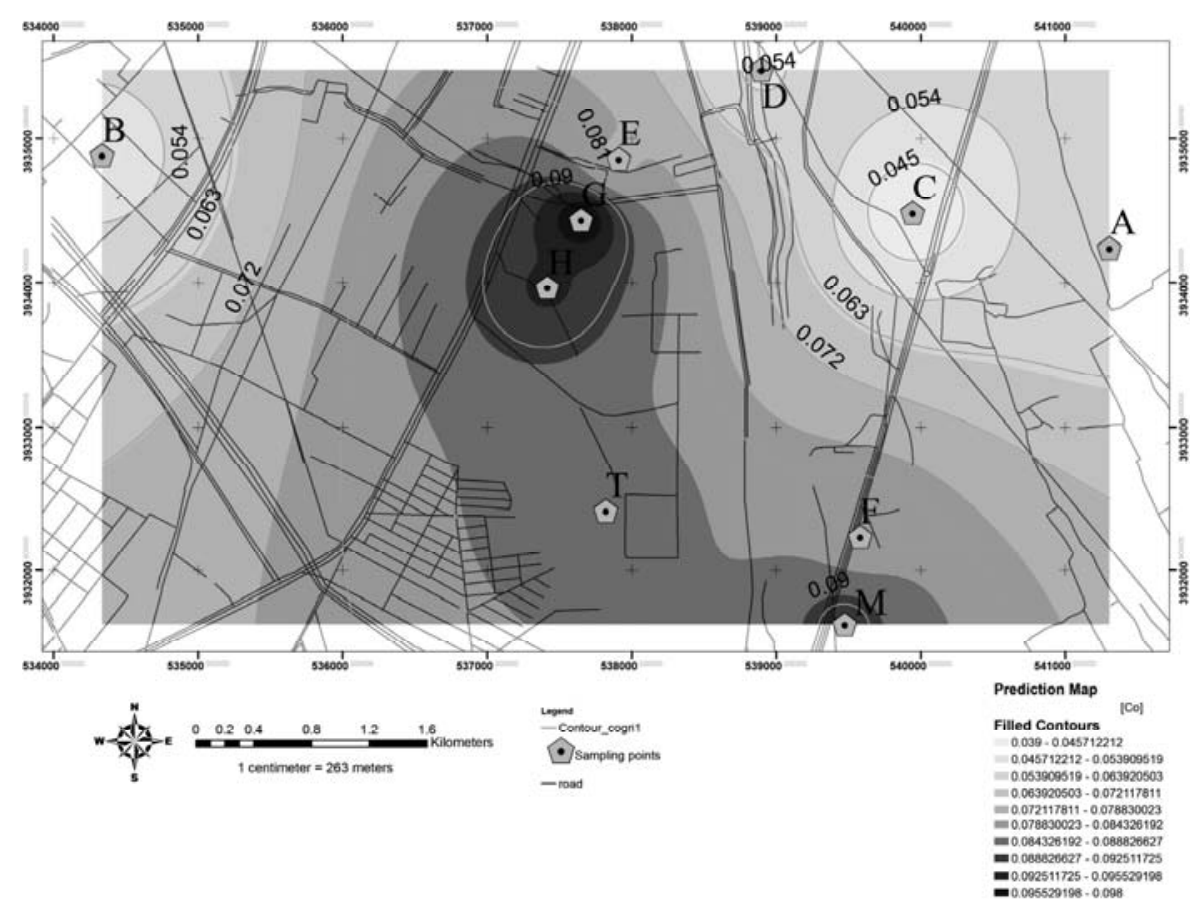

Fig. 6. Spatial distribution of Co as calculated by interpolation method for leafy vegetables using information system 


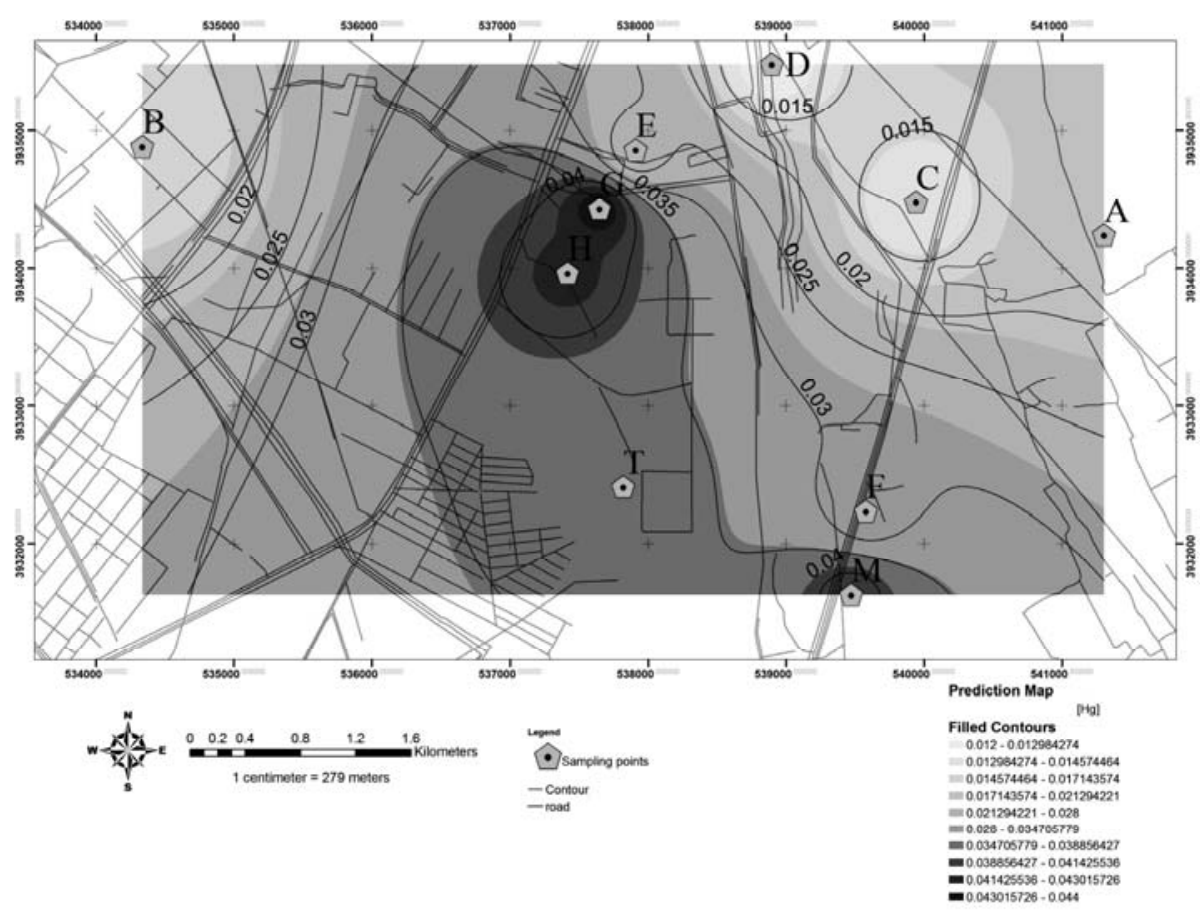

Fig. 7. Spatial distribution of $\mathrm{Hg}$ as calculated by interpolation method for leafy vegetables using information system

\section{Arsenic}

The study results demonstrated that the maximum concentration of arsenic was found in $\operatorname{spinach}\left(0.811 \pm 0.028 \mu \mathrm{g} \cdot \mathrm{g}^{-1}\right)$. The mean concentrations of arsenic in leafy vegetables, agricultural soils and well waters were $0.508 \pm 0.028 \mu \mathrm{g} \cdot \mathrm{g}^{-1}, 1.08 \pm 0.062 \mu \mathrm{g} \cdot \mathrm{g}^{-1}$ and $0.76 \pm 0.02 \mu \mathrm{g} \cdot \mathrm{L}^{-1}$ respectively. Arsenic had a low concentration in edible vegetables, agricultural soils and well waters as compared with WHO and EPA references. The highest arsenic levels ccurred in G point (Figure 8). The mean concentration of arsenic in industrial waste water of Shahre-Ray regions was $6.37 \pm 0.24 \mu \mathrm{g} \cdot \mathrm{L}^{-1}$.

\section{Conclusions}

The concentration of heavy metals ( $\mathrm{V}, \mathrm{Ni}, \mathrm{Co}, \mathrm{As}$ and $\mathrm{Hg}$ ) in soil, well water, waste water and leafy edible vegetables in ten points of Shahre-Ray industrial region were investigated and analyzed. In the proposed method, the vegetables and soil

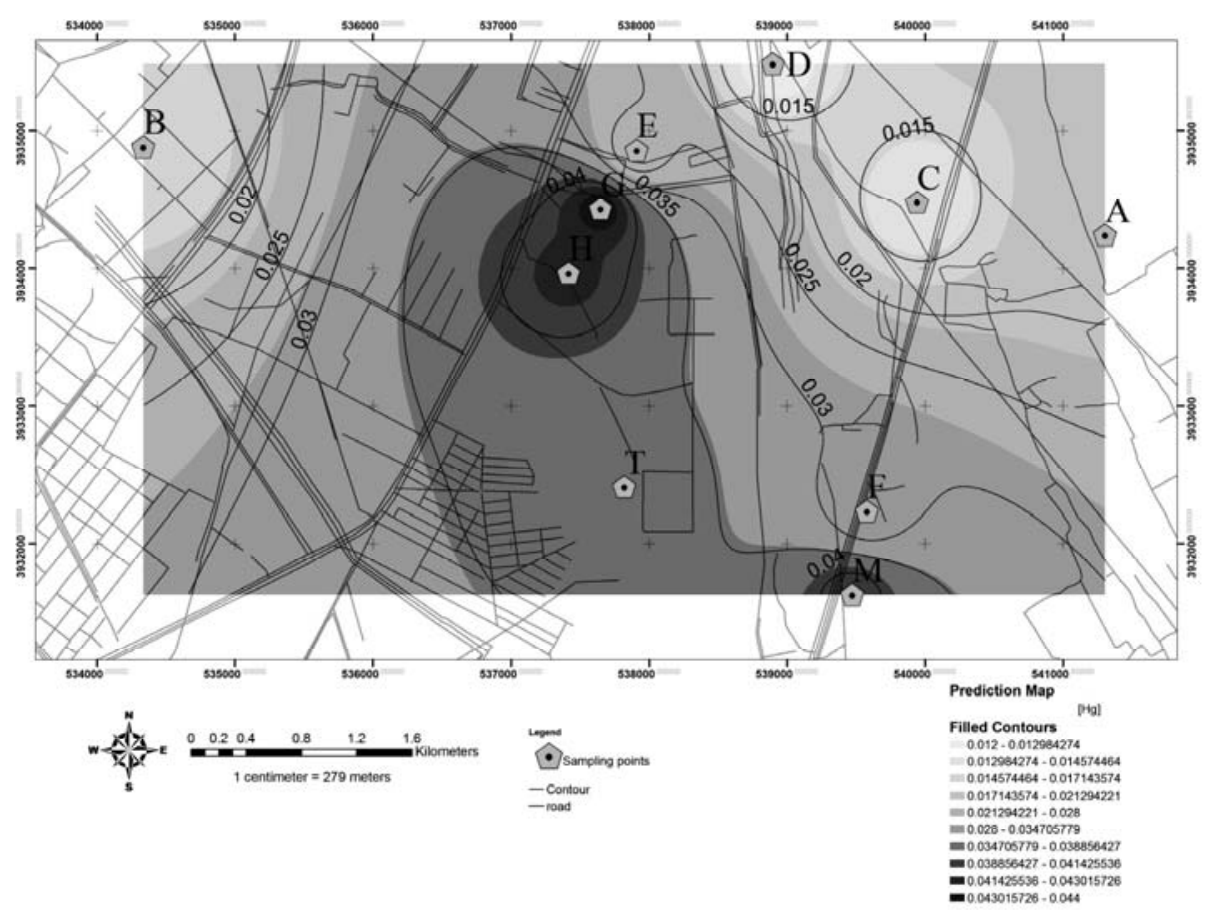

Fig. 8. Spatial distribution of As as calculated by interpolation method for leafy vegetables using information system 
samples was digested with microwave digestion equipment and then the concentration of heavy metals was determined by variable techniques of atomic absorption spectrometry (CV-AAS, HGAAS and ET-AAS). The results of this study showed that six points of sampling ( $g, f, h, m, t$ and e) had higher concentration of heavy metals than other points. Figures 4-8 present the spatial distribution of values of the predicted heavy metal concentration calculated for five sampling points by ArcGIS software. GIS implementation to estimate the levels of heavy metal concentration at unmeasured locations provides important information for region administration to enable assessments of hazard conditions in the vicinity of industrial zone, through spatial identification and quantification of heavy metals concentration. Thus, the vicinity of the industrial region can be labeled as the most polluted area in the present study. The results of the determination of heavy metals in soils and well waters revealed that the mean concentrations of $\mathrm{V}, \mathrm{Ni}, \mathrm{Co}, \mathrm{As}$ and $\mathrm{Hg}$ were achieved $\left(0.457 \pm 0.027 \mu \mathrm{g} \cdot \mathrm{g}^{-1}, 2.452 \pm 0.032 \mu \mathrm{g} \cdot \mathrm{g}^{-1}\right.$, $0.567 \pm 0.032 \mu \mathrm{g} \cdot \mathrm{g}^{-1}, 1.08 \pm 0.062 \mu \mathrm{g} \cdot \mathrm{g}^{-1}$ and $0.085 \pm 0.006$ $\left.\mu \mathrm{g} \cdot \mathrm{g}^{-1}\right)$ and $\left(182.23 \pm 7.45, \mu \mathrm{g} \cdot \mathrm{L}^{-1} 172.43 \pm 4.13 \mu \mathrm{g} \cdot \mathrm{L}^{-1}, 126.47\right.$ $\pm 5.19 \mu \mathrm{g} \cdot \mathrm{L}^{-1}, 0.76 \pm 0.02 \mu \mathrm{g} \cdot \mathrm{L}^{-1}$ and $\left.0.15 \pm 0.01 \mu \mathrm{g} \cdot \mathrm{L}^{-1}\right)$ respectively. In vegetables samples, the mean concentrations of $\mathrm{V}, \mathrm{Ni}, \mathrm{Co}$, As and $\mathrm{Hg}$ were obtained $0.093 \pm 0.005 \mu \mathrm{g} \cdot \mathrm{g}^{-1}$, $0.775 \pm 0.043 \mu \mathrm{g} \cdot \mathrm{g}^{-1}, 0.073 \pm 0.004 \mu \mathrm{g} \cdot \mathrm{g}^{-1}, 0.508 \pm 0.028 \mu \mathrm{g} \cdot \mathrm{g}^{-1}$ and $0.027 \pm 0.002 \mu \mathrm{g} \cdot \mathrm{g}^{-1}$ respectively. In Shahre-Ray region, the low concentration of mercury and arsenic in edible vegetables and high concentrations of cobalt, nickel and vanadium in edible vegetables and well waters were obtained as compared with WHO/FAO. So, the heavy metals such as mercury and arsenic have no hazardous effect on human health and environment pollution in Shahre-Ray regions. In addition, agricultural soils had low concentration of heavy metals in all of sampling points in farms of Shahre-Ray regions. Therefore, high concentration of $\mathrm{Co}, \mathrm{V}$, Ni in waste water can only cause environmental pollution in well water and edible vegetables. In consequence, the results showed that the correlation coefficients between well water and vegetables were significant statistically. The best suggestion is using pure or refinement water for cultivation and growing vegetables, controlling heavy metals in well and waste water continuously and using another source of water for cultivation.

\section{References}

[1] Amin, N., Hussain, A., Alamzeb, S. \& Begum, S. (2013). Accumulation of heavy metals in edible parts of vegetables irrigated with waste water and their daily intake to adults and children, District Mardan, Pakistan, Food Chemistry, 136, pp. 1515-1523.

[2] Abbas, M., Parveen, Z., Iqbal, M., Iqbal, S., Ahmed, M. \& Bhutto, R. (2010). Monitoring of toxic metals (cadmium, lead, arsenic and mercury) in vegetables of Sindh, Pakistan, Journal of Engineering Science and Technology, 6, pp. 60-65.

[3] Asdeo, A. \& Loonker, S. (2011). A comparative analysis of trace metals in vegetables, Research Journal of Environmental Toxicology, 5, pp. 125-132.

[4] Agency for Toxic Substances and Disease Registry (ATSDR), Interaction profile for arsenic, cadmium, chromium and lead, Atlanta, GA: U.S. Department of Health and Human Services, (2010).

[5] Agency for Toxic Substances and Disease Registry (ATSDR), Toxicological profile for Nickel, U.S. Department of Health, Atlanta, GA, (2005).

[6] Aurilio, A., Mason, R. \& Hemond, H. (1994). Speciation and fate of arsenic in three lakes of the Aberjona watershed, Environmental Science \& Technology, 28, pp. 577-585.

[7] American Conference of Governmental Industrial Hygienists (ACGIH), U.S Documentation of the Threshold Limit Values and Biological Exposure Indices, 2011.

[8] Cao, H., Chen, J., Zhang, J., Zhang, H., Qiao, L. \& Men, Y. (2010). Heavy metals in rice and garden vegetables and their potential health risks to inhabitants in the vicinity of an industrial zone in Jiangsu, China, Journal of Environmental Sciences, 22, pp. 1792-1799.

[9] Ciesielczuk, T., Rosik-Dulewska, C. \& Kochanowska, K. (2014). The influence of biomass ash on the migration of heavy metals in the flooded soil profile, Archives of Environmental Protection, 40, pp. 3-15.

[10] Cheraghi, M., Lorestani, B. \& Yousefi, N. (2009). Effect of waste water on heavy metal accumulation in Hamedan Province vegetables, International Journal of Botany, 5, pp. 190-193.

[11] Chakraborti, D., Rahman, M., Paul, K., Chowdhury, U., Sengupta, M., Lodh, D., Chanda, C., Saha, K. \& Mukherjee, S. (2002). Arsenic calamity in the Indian subcontinent, Talanta, 58, pp. 3-22.

[12] Edem, C., Dosunmu, M. \& Bassey, F. (2009). Distribution of heavy metals in leaves, stems and roots of fluted Pumpkin (Telferia occidentatis), Pakistan Journal of Nutrition, 8, pp. 222-224.

[13] Environmental Protection Agency (EPA), (2010). Designation of Hazardous Substances, 40 CFR 302.4, Washington DC.

[14] Foo, S. \& Tan, T. (1998). Elements in the hair of South-east Asian islanders, Science of The Total Environment, 209, pp. 185-192.

[15] Gharib, A., Fatoorechian, S. \& Ahmadiniar, A. (2003). Determination of essential major and trace elements in daily diets by comparative methodologies and alterations, Journal of Trace Elements in Medicine and Biology, 4, pp. 21-32.

[16] Helgesen, H. \& Larsen, E. (1998). Bioavailability and speciation of arsenic in carrots grown in contaminated soil, Analyst, 123, pp. 791-796. 
[17] Itanna, F. (2002). Metals in leafy vegetables grown in Addis Ababa and toxicological implications, The Ethiopian Journal of Health Development, 16, pp. 295-302.

[18] Jonczak, J. \& Parzych, A. (2014). The content of heavy metals in the soil and litterfall an a beech-pine-spruce stand in northern Poland, Archives of Environmental Protection, 40, pp. 67-77.

[19] Jarup, L. (2003). Hazards of heavy metal contamination, British Medical Bulletin, 68, pp. 167-182.

[20] Jiang, H., Qin, Y. \& Hu, B. (2008). Dispersive phase microextraction (DLPME) combined with graphite furnace atomic absorption spectrometry (GFAAS) for determination of trace Co and Ni in environmental water and rice samples, Talanta, 74, pp. 1160-1165.

[21] Jawad, I. (2010). The level of heavy metals in selected vegetables crops collected from Baghdad city markets, Pakistan Journal of Nutrition, 9, pp. 683-685.

[22] Jonge, C. \& Swami, K. (2010). ICP-MS determination of lead isotope ratios in legal and counterfeit cigarette tobacco samples, Isotopes in Environmental and Health Studies, 46, pp. 484-494.

[23] Karanja, N., Njenga, M., Prain, G., Kanethe, E. \& Kironchi, G. (2010). Assessment of environmental and public health hazards in waste water used for urban agriculture in Nairobi, Kenya, Tropical and Subtropical Agroecosystems, 12, pp. 85-97.

[24] Langmuir, D., Chrostowski, P., Chaney, B.U.R. \& Vigneault, S. (2004). Environmental Protection Agency (EPA), Environmental Chemistry of Metals.

[25] Maleki, A. \& Zarasvand, M. (2010). Heavy metals in selected edible vegetables and estimation of their daily intake in Sanandaj, Iran, Southeast Asian Journal of Tropical Medicine and Public Health, 39, pp. 335-340.

[26] Manzoori, J. \& Bavali-Tabrizi,A. (2003). Cloud point preconcentration and flame atomic absorption spectrometric determination of cobalt and nickel in water samples, Microchimica Acta, 141, pp. 201-207.

[27] Mizuguchi, H., Ishida, M., Takahashi, T. \& Sasaki, A. (2011). Ultra-trace determination of lead(ii) in water using electrothermal atomic absorption spectrometry after preconcentration by solid-phase extraction to a small piece of cellulose acetate type membrane filter, Analytical Sciences, 27, pp. 85-87.

[28] Mohammadi, Z., Shamspur, T., Karimi, A. \& Naroui, E. (2012). Preconcentration of trace amounts of Pb(ii) ions without any chelating agent by using magnetic iron oxide nanoparticles prior to ETAAS determination, Scientific World Journal, Article ID 640437, pp. 1-6.

[29] National Health and Nutrition Examination Survey, Atlanta Centers for Disease Control (ACDC) (2010) GA 30333.

[30] Pandey, J., Shubhashish, K., Pandey, R., Kanethe, E. \& Kironchi, G. (2010). Heavy metal contamination of Ganga River at Varanasi in relation to atmospheric deposition, Journal of Tropical Ecology, 51, pp. 365-373.

[31] Rehder, D. (2003). Biological and medicinal aspects of vanadium, Inorganic Chemistry Communications, 6, pp. 604-617.

[32] Safavi, A., Abdollahi, H., Hormozi Nezhad, M. \& Kamali, R. (2004). Cloud point extraction, precocentration and simultaneous spectrophotometric determination of nickel and cobalt in water samples, Spectrochimica Acta Part B, 60, pp. 2897-2901.

[33] Safavi, A., Iranpoor, N., Saghir, N. \& Momeni, S. (2006). Glycerol-silica gel: a new solid sorbent for preconcentration and determination of traces of cobalt(II) ion, Analytica Chimica Acta, 569, pp. 139-144.

[34] Smith, A., Goycolea, M., Haque, R. \& Biggs, M. (1998). Marked increase in bladder and lung cancer mortality in a region of northern Chile due to arsenic in drinking water, American Journal of Epidemiology, 147, pp. 660-669.

[35] Sharma, R., Agrawal, M. \& Marshal, F. (2009). Heavy metals in vegetables collected from production and market sites of a tropical urban area of India, Food and Chemical Toxicology, 47, pp. 583-591.

[36] Skoog, D., Holler, F. \& Crouch, S. (2002). Principles of instrumental analysis, Thomson Brooks Cole, New York 2002.

[37] Tsuda, T., Babazono, A., Ogawa, T., Hamad, H., Mino, Y., Aoyama, H., Kuramatani, N., Nagira, T., Harada, M. \& Inomata, S. (1992). Inorganic arsenic: A dangerous enigma for mankind, Applied Organometallic Chemistry, 6, pp. 309-322.

[38] Tondel, M., Rahman, M., Magnuson, A., Chowdhury, I., Faruquee, M. \& Ahamad, S. (1999). The relationship of arsenic levels in drinking water and the prevalence rate of skin lesions in Bangladesh, Environmental Health Perspectives, 107, pp. 727-729.

[39] Tang, C., Li. A., Huang, H., Cheng, X., Gao, Y., Chen, H., Huang, Q., Luo, Y., Xue, Y., Zuo, Q. \& Cui, L. (2012). Effects of lead pollution in SY River on children's intelligence, Life Sciences, 9, pp. 458-464.

[40] Uchida, S., Tagami, K. \& Hirai, I. (2007). Soil-to-plant transfer factors of stable elements and naturally occurring radionuclids upland field groups collected in Japan, Journal of Nuclear Science and Technology, 44, pp. 628-640.

[41] Vela, N., Heitkemper, D. \& Stewart, K. (2001). Arsenic extraction and speciation in carrots using accelerated solvent extraction, liquid chromatography and plasma mass spectrometry, Analyst, 126, pp. 1011-1017.

[42] Vela, N. \& Heitkemper, D. (2004). Total arsenic determination and speciation in infant food products by ion chromatography-inductively coupled plasma-mass spectrometry, Journal of AOAC International, 87, pp. 244-252.

[43] Vinogradov, A. (1959). The geochemistry of rare and dispersed chemical elements in soil, Consultants Bureau, New York 1959. 
[44] World Health Organization (WHO), (2008). Guidelines for Drinking Water Quality, Second addendum to 3 Ed.

[45] Wilhelm, M. \& Ritz, B. (2003). Residential proximity to traffic and adverse birth outcomes in Los Angeles County, California, 1994-1996, Environmental Health Perspectives, 111, pp. 207-216.

[46] Zahir, E., Imran, I. \& Mohyuddin, S. (2009). Market Basket Survey of selected metals in fruits from Krachi city (Pakistan), Journal of Basic \& Applied Sciences, 5, pp. 47-52. 